\title{
Potential of Malawi's medicinal plants in Covid-19 disease management: A review
}

\author{
Ibrahim Chikowe ${ }^{1 *}$, Andrew G. Mtewa ${ }^{2}$, David Tembo ${ }^{3}$, Dallas Smith ${ }^{1}$, Edna Ibrahim ${ }^{3}$, Bonface \\ Mwamatope $^{4}$, Justin Nkhungulu ${ }^{1}$, Peter Kumpalume ${ }^{1}$, Alfred Maroyi ${ }^{5}$
}

\author{
1. Pharmacy Department, College of Medicine, University of Malawi, Blantyre, Malawi/Kamuzu University of Health Sciences \\ 2. Chemistry Section, Malawi Institute of Technology, Malawi University of Science and Technology, Thyolo, Malawi. \\ 3. The Polytechnic, University of Malawi, Blantyre, Malawi/Malawi University of Business and Applied Sciences \\ 4 University of Livingstonia, Rumphi, Malawi. \\ 5. University of Fort Hare, Alice, South Africa.
}

*Correspondance: chikoweib@yahoo.co.uk; ichikowe@medcol.mw.

\begin{abstract}
The Coronavirus Disease 2019 (COVID-19) caused by severe acute respiratory syndrome coronavirus 2 (SARS-CoV-2) has triggered an international pandemic that has led to significant public health problems. To date, limited evidence exists to suggest that drugs are effective against the disease. As possible treatments are being investigated, herbal medicines have shown potential for producing novel antiviral agents for the COVID-19 disease.

Aim

This review explored the potential of Malawi's traditional medicinal plants for the management of COVID-19.

Methods

The authors searched on PubMed and Google scholar for medicinal plants that are used in Malawi and published in openly available peer reviewed journals. Plants linked with antiviral treatment, anti-COVID-19 activity or COVID-19 symptoms management were targeted. These included activity against pneumonia, inflammation, cough, difficulty in breathing, pain/aches, fever, diarrhoea, rheumatism, fatigue, asthma, immunocompromised and cardiovascular diseases.

Results

11 studies were found with 306 plant species. 127 plant species had at least one COVID-19 related pharmacological activity. Of these plant species, the number of herbal entities used for each indication was: pain/aches (87), fever (2), pneumonia (9), breathing/asthma problems (5), coughing (11), diarrhoea (1), immunosuppression (8), blood issues (10), fatigue (2), heart problems (11), inflammation (8), rheumatism (10) and viral diseases (12). Thirty (30) species were used for more than one disease and Azedarachta indica topped the list (6 of the 13 COVID-19 related diseases). The majority of the species had phytochemicals known to have antiviral activity or mechanisms of actions linked to COVID-19 and consequent diseases' treatment pathways.

Conclusion

Medicinal plants are a promising source of compounds that can be used for drug development of COVID-19 related diseases. This review highlights potential targets for the World Health Organization and other research entities to explore in order to assist in controlling the pandemic.
\end{abstract}

Key Words: traditional medicine, herbal products, corona virus, drug development, screening

\section{Introduction}

Viruses are pathogens that cause communicable diseases like flu, AIDS and Ebola and increasing evidence shows that some viruses play a role in the disease mechanism of some non-communicable diseases like cancers, Alzheimer's disease and type 1 diabetes with high morbidity and mortality rates worldwide. ${ }^{1}$ Most of these diseases have proved hard to cure. $^{2-5}$ Viruses cause epidemics that emerge and re-emerge and are easily transmitted to different locations due to increased global travel and rapid urbanization. Emergence of novel viruses and rapid mutation of old viruses make drug as well as vaccine development challenging and these are some of the major reasons why there has not been significant development of effective drugs or vaccines against many viruses. Notable viruses that have caused outbreaks with significant public health implications worldwide include dengue virus, influenza virus, measles virus, severe acute respiratory syndrome (SARS) virus, and West Nile virus and the recently discovered severe acute respiratory syndrome corona virus 2 (SARS-CoV-2). ${ }^{6-9}$ The SARS-CoV-2 is a novel virus that was discovered in 2019 in Wuhan City of Hubei Province in China and has spread rapidly throughout the world, causing serious health care burden. The virus causes a disease called COVID-19 disease that affects all populations of people, but the elderly and those with underlying medical conditions are at a higher risk of morbidity and mortality. ${ }^{10}$ Being a novel disease caused by a novel virus, knowledge about the virus and the disease is limited and keeps on developing daily. ${ }^{11}$

SARS-CoV-2 is a $60 \mathrm{~nm}$ to $140 \mathrm{~nm}$ diameter, enveloped, positive sense RNA virus (11) belonging to the Coronaviruses (CoVs) that are generally enveloped viruses with single-stranded RNA genome. CoVs have the largest genomes to date among RNA viruses that range from approximately 26 to 32 kilobases. They replicate by genes encoding for viral structural proteins such as nucleocapsids (N), membranes (M), spikes (S), and envelopes (E), which play significant roles in viral integrity. ${ }^{12}$ However, there are other commonly studied proteins that have been widely targeted 
for drug development. These include papain-like protease (PLpro), 3c-like protease (3CLpro) and spike protein ${ }^{13-16}$.

Coronaviruses infections are well known for causing enteric, respiratory and central nervous system diseases in animals and humans. ${ }^{17}$ The nomenclature of coronaviruses originates from spike-like projections on its surface, which gives it a shape similar to a crown when viewed under an electron microscope. ${ }^{16,18}$ The gene sequence of SARS-CoV-2, the coronavirus responsible for COVID-19, suggests that its proteins are similar to those of South Asia Respiratory Syndrome (SARS) or Middle East Respiratory Syndrome (MERS). ${ }^{19,20}$ Hence, drugs, compounds and medicinal plants or extracts known to inhibit these proteins in SARS and MERS could be promising leads for COVID-19 drug development.

COVID-19 is transmitted by large water droplets released by infected people (symptomatic or asymptomatic) when they cough and sneeze, and they survive in these droplets that are spread on the surfaces or individual's bodies. ${ }^{21}$ Higher viral loads can be found in the nasal cavity than the throat. ${ }^{22}$ People are infected by touching their nose, eyes or mouth after touching surfaces contaminated with SARS-CoV-2.23,24 The virus enters the respiratory mucosa using angiotensin converting enzyme receptor 2 (ACE-2). ${ }^{25}$ The virus can easily be killed by common disinfectants such as ethanol (preferably $\geq 80 \%$ ), sodium hypochlorite or hydrogen peroxide. ${ }^{23,24}$

COVID-19 patients can be symptomatic, pre-symptomatic, or asymptomatic. ${ }^{26}$ Common clinical features are fever, dry cough, sore throat, fatigue, headache, conjunctivitis, myalgia and breathlessness as well as loss of taste or smell. ${ }^{27-29}$ Some patients also develop pneumonia and respiratory failure and may die within weeks. The latter scenario is associated with an extreme increase in inflammatory cytokines (cytokine storm), especially IL2, IL7, IL10, GCSF, IP10, MCP1, MIP1A, and TNF ${ }^{30}$ The COVID-19 disease is also associated with complications such as acute lung injury, Acute Respiratory Distress Syndrome (ARDS), shock, and acute kidney injury.

Currently, there are no approved treatment medicines in use for COVID-19 disease. The disease is being managed by prevention of transmission (face masks and washing hands with soap and water or using hand sanitizer), maintaining hydration and nutrition, controlling fever and cough, provision of oxygen and renal replacement therapy. The use of these interventions varies by availability, access, location and disease severity. Therefore, there is a need to discover, design or develop novel efficacious and cost-effective antivirals as the search for effective vaccines continues. ${ }^{9}$

Several approaches are being implemented to tackle COVID-19, one of which is the repurposing of widely used conventional and herbal medicines. ${ }^{31}$ Antiviral drugs (ribavirin, lopinavir-ritonavir based on experience in SARS and MERS), combination therapy of oseltamivir, ganciclovir and lopinavir-ritonavir, and remdesivir (broad spectrum antiRNA drug developed for Ebola) have been tested. Remdesivir, the only antiviral option showing benefit to date, has shown statistically significant improvements in time to recovery in hospitalized patients in comparison with placebo. ${ }^{32}$ Short term therapy with low-to-moderate dose corticosteroids (such as dexamethasone) in COVID-19 ARDS, intravenous immunoglobulin therapy, arbidol (antiviral drug), interferons, hydroxychloroquine and plasma of patients recovered from COVID-19 have been trialled. Despite preliminary reports showing that dexamethasone may decrease mortality rates among critically ill patients, more evidence about its efficacy and safety, along with other agents, are needed before these treatment options are fully recommended for use. . $^{30,33-39}$

Traditional medicines, especially Chinese herbs, have been tested for use in COVID-19. ${ }^{33}$ Aanouz et al., (2020) used computational techniques to evaluate the inhibition potential of compounds isolated from plants used in Morocco against COVID-19 virus. Sixty seven (67) compounds isolated from aromatic and medicinal plants were found and selected for molecular docking studies that used energy of interaction between the compound's functional groups and the corona virus (SARS-COV-2 spike protein) as one of the criteria for anti-corona virus effect. Chloroquine was used as a standard (interaction energy of $-6 \mathrm{kcal} / \mathrm{mol}$ ). Eleven (11) molecules showed a good interaction with the target, but the three greatest activities were for Crocin from Crocus sativus L. (-8.2kcal $/ \mathrm{mol}$ ), Digitoxigenin (Nerium oleander L., $-7.2 \mathrm{kcal} / \mathrm{mol}$ ) and $\beta$-Eudesmol (Laurus nobilis L., $-7.1 \mathrm{kcal} /$ $\mathrm{mol})$. Experimental data also showed that they had antiviral activity. ${ }^{40}$ For example, Crocin was found in vitro to be an inhibitor of the replication of Herpes Simplex Virus (HSV) before and after virion entry in Vero cells, and its plant/ herbal medicine source showed promise for use as an antiHSV and anti-Human Immunodeficiency Virus (HIV) agent. ${ }^{41}$ Derivatives of Digitoxigenin are used as antiviral and anticancer inhibitors, while $\beta$-Eudesmol has substantial antibacterial and antiviral activity. ${ }^{42-43}$

Zhang et al., (2020) executed a rational computer-based screening study aimed at identifying Chinese medical herbs and compounds with antiviral activity against respiratory infections and COVID-19. This computer-based study searched through literature for natural compounds and their respective traditional Chinese medicinal plants known to fight against MERS or SARS coronavirus. Docking studies were completed to analyse their potential for direct interaction with SARS-COV-2 protein, followed by biological activity search from literature. Thirteen (13) out of the 115 compounds found in the search of traditional Chinese medicines exhibited potential for anti-COVID-19 activity and 125 screened Chinese herbs contained 2 or more of the 13 compounds. A search for pharmacological activity showed that 26 of the 125 herbs had antiviral activity in respiratory infection, and that they regulated viral infection, immune/inflammation reactions and response to hypoxia. ${ }^{44}$ Hui et al., (2020) evaluated studies that tested the use of Chinese medicine (CM) as prophylaxis on people exposed to SARS and H1N1 influenza in clinical trials, cohort or other population studies. Results showed that the Chinese medicines performed well as prophylaxis, an effectiveness that has also been recorded in historical practice with $\mathrm{CM} .{ }^{45}$ During the COVID-19 epidemic, several CM products were also tested in humans for prevention of the epidemic effects and selection of the $\mathrm{CM}$ was based on historical use and previous experimental results in similar viral epidemics. The CM used in the studies included radix astragali (Astragalus propinquus Schischkin), radix glycyrrhizae (Glycyrrbiza uralensis Fisch. ex DC.), radix saposhnikoviae (Saposhnikovia divaricata (Turcz.) Schischk.), rhizoma atractylodis macrocephalae (Atractylodes macrocephala Koidz.), lonicerae japonicae flos (Lonicera japonica Thunb.) and fructus forsythia (Forsythia suspensa (Thunb.) Vahl.). This study revealed that historical use and previous use of the $\mathrm{CM}$ in similar epidemics provided clues for selection of CM use and efficacy in COVID-19. ${ }^{45,46}$ 
Plant extracts of Lycoris radiata (L'Hér.) Herb., Artemisia annua L., Pyrrosia lingua (Thunb.) Farw. and Lindera aggregata (Sims.) Kosterm. were also evaluated and found to have anti-SARS activity after a screening exercise of hundreds of $\mathrm{CMs}^{47}$

Apart from whole plant extracts, phytochemicals have been evaluated and shown potential for activity against COVID-19 disease, including Saikosaponins Types A, B2, $\mathrm{C}$, and D (phytochemicals belonging to naturally occurring triterpene glycosides). For example, Saikosaponins from Bupleurum spp., Heteromorpha spp., Scrophularia scorodonia L. have showed antiviral activity against a human and bat corona virus $\mathrm{HCoV}-229 \mathrm{E}$, that together with OC43, causes the common cold. ${ }^{34,47}$

Furthermore, inhibitors of SARS enzymes (nsP13 helicase and 3CL protease) have also been isolated from plants. For example, myricetin is a flavonoid polyphenolic compound that has anti-oxidant properties. ${ }^{48}$ Scutellarein, a flavone isolated from Scutellaria lateriffora L., has shown activity against SARS. ${ }^{35,49}$ Phenolic compounds isolated from Isatis tinctoria L., Torreya nucifera (L.) Siebold \& Zucc. and a water extract of Houttuynia cordata Thunb. have also exhibited antiviral mechanisms against SARS. ${ }^{50}$ These water extracts have been particularly known to inhibit viral 3CL protease as well as blocking viral RNA-dependent RNA-polymerase activity. ${ }^{51}$

Herbal-western medicine combination therapies of lopinavir/ritonavir (anti-HIV medicines), arbidol (broadspectrum antiviral) and CM Shufeng Jiedu capsule as well as lopinavir/ritonavir and CM Shufeng Jiedu capsule have also been tested clinically. Clinical observations for both herbalwestern medicine combination therapies treated patients showed that the TCMs treatments were effective in a majority of the patients that were treated with them, which showed that the TCMs can play a role in treating COVID-19. The Herbal-western medicine combination therapies were very important in the treatment of the viral pneumonia. It was found that more studies were needed to produce conclusive results on the curing capability of the combination therapies on COVID-19. ${ }^{52}$

In the search for chemotherapy for COVID-19, there are different sources of medicines, one of which is traditional medicines or medicinal plants. In the African region including Malawi, treatment options commonly stem from medicinal plants due to their abundance and untapped potential. $80 \%$ of the population in this region relies on medicinal plants as a primary health care option. ${ }^{53}$

Several studies have already started exploring plants for COVID-19 cure. $^{32,54}$ There may be other unexplored plants that have potential for producing a cure for the disease or addressing mild to severe symptoms. Therefore, it is important to analyse the plants that have shown potential for COVID-19 activity and study plants with similar attributes. The following section explores the literature on studies that have evaluated the efficacy of medicinal plants on SARSCoV-2 as well as searching for plants with similar antiviral potential in Malawi. For a plant or its isolated compounds to have potential for use in COVID-19, it should be able to kill or inactivate the virus or alleviate the symptoms and complications caused by coronavirus infection.

\section{Significance of the Study on Medicinal plants with potential for use in COVID-19 in Malawi}

The WHO recommends supportive care options such as the use of supplemental oxygen through ventilators but these interventions are too expensive for most low-income countries with under resourced healthcare systems. ${ }^{55,56}$ Furthermore, there are gaps in trained health care providers for such interventions. ${ }^{57}$ The majority of biomedical COVID-19 treatment options available lack data to support their effectiveness. ${ }^{55}$ Options that are showing some clinical promise have soaring prices and frequent stock outs. ${ }^{58}$ Hence, medicinal plants may be alternatives for individuals in Malawi and other developing countries. Although there have been in-vitro studies that have shown activity for various aspects of COVID-19, there hasn't been a study completed in Malawi to assess the efficacy or toxicity of medicinal plants. Although various medicinal plants have been analysed abroad, these data cannot be extrapolated to the same species in Malawi since geographical differences have been identified in medicinal plants' composition and activity. ${ }^{59}$ Hence, this study seeks to provide baseline data for use in the discussion of Malawi's medicinal plants use in COVID-19 treatment. Furthermore, it may confirm or refute widely-circulating arguments or fears concerning the use of medicinal plants against COVID-19. This will be achieved by the following specific objectives: To examine published ethnobotanical studies conducted in Malawi in order to identify the medicinal plants with demonstrated activity or potential for activity against COVID-19 disease. To evaluate the literature for reported pharmacological properties of medicinal plants found to have potential for use in COVID-19 disease.

\section{Methods}

The authors searched for studies on medicinal plants that are used in Malawi that met the following inclusion criteria: Published in peer reviewed journals that were openly available online between January 1994 and July 2020. Had medicinal plants reported to be found and used in Malawi by at least one ethnobotanical survey as well as being tested in a laboratory.

The plant had been linked with antiviral or anti-COVID-19 use or against the symptoms of COVID-19. The key words that were used on Google Scholar and PubMed were: Ethnobotany, ethnobotanical survey, Malawi, Malawi herbal medicine, Malawi herbalist, Malawi medicinal plant, Malawi phytochemical screening, Malawi herbals and traditional medicine. Eleven (11) studies met the inclusion criteria while over 93 studies were excluded because plants reported were not cited in the ethnobotanical surveys reported in Malawi. All plant extracts that had potential for use in COVID-19 were considered. That potential was shown by its local use on viral infections or antiviral activity (e.g., curative action against pneumonia and inflammation), COVID-19 symptoms (symptom management of cough, difficulty in breathing, pain/aches, fever, diarrhoea, rheumatism and fatigue) and risk factors (high risk comorbidities like asthma, immunocompromise and cardiovascular diseases).

For the plants that met the above criteria, further searches were conducted on Google Scholar and PubMed using key words: scientific or botanical name of the plant, phytochemicals, bioactivity and pharmacological activity to find out if there have been any laboratory studies in Malawi or any other country to evaluate their biological or pharmacological activity on COVID-19 and consequent diseases. Summaries of all the studies and plants were created using Microsoft Excel. 


\section{Results}

The literature search found a total of 11 studies. $^{60-70}$ Plant list extraction yielded 306 plant species thereafter removing species that were irrelevant or not identified by a botanist (Additional File 1: Table 1). Of these 306 medicinal plants, 127 plants were found to manage at least one of the symptoms related to COVID-19 or were found to be used for the management of viral infections (Additional File 2: Table 2). Table 3 shows a summary of the results shown in the Additional File 2.

This study revealed that 87 of 127 medicinal plants could be used for pain or aches management, and two of those for fever management (Azadirachta indica A. Juss. and Pyrenacantha kaurabassana Baill.). Pneumonia is anothersymptom associated with COVID-19. In this study, we found 9 medicinal plants that are used traditionally to manage pneumonia and 5 that have potential for use in managing breathing or asthma problems. Other diseases associated with COVID-19 for which we identified traditional medicines included coughing (11 plants), diarrhoea (1 plant), immunosuppression (8 plants), blood related issues (10 plants), fatigue (2 plants), heart problems (11 plants), inflammation (8 plants) and rheumatism (10 plants). COVID-19 is a viral infection and any medicinal plant used for viral diseases has potential of being tested on coronavirus. There were 12 plants found to have been used for viral infections or diseases.

Of the 127 medicinal plants with potential to manage COVID-19 related diseases or symptoms, 30 had more than one disease for which they could be used. Azedarachta indica topped the list with being used for 6 of the 13 COVID-19 related diseases, high risk comorbidities and symptoms followed by Moringa oleifera Lam. Pyrenacantha kaurabassana Baill. and Sclerocarya birrea (A. Rich.) Hochst. that could be used on 4 aspects of COVID-19. Analysis of these 30 plants revealed that they covered all types of the diseases except one; fatigue. Table 4 shows the 30 plant species and their associated benefits for COVID-19 management.

\section{Pharmacological effects of the plants}

The 30 plants with activity against one or more aspects of COVID-19 were considered more user-friendly since one entity can be used for multiple purposes. This may lead to a decreased incidence of toxicity and interactions. However, it should also be pointed out that the use of medicinal plants potentially leads to the administration of multiple active compounds (drug promiscuity), and is dangerous as it risks drug resistance and adverse events from unknown drug-drug interactions. Some of the components therein would be administered to the patient in suboptimal doses and others in overdoses, with chances of drug resistance and toxicity. ${ }^{71}$

On the other hand, documented evidence exists that suggests that the use of more than one medicinal plant (polyherbalism) improves the efficacy of the products as well as convenience for patients during administration (dose and frequency). Research also suggests that combining medicinal plants with more than one pharmacological effect can provide even greater benefit. ${ }^{72}$ Therefore, the 30 plants with multiple COVID-19 activities were evaluated further using literature review to determine if any studies had been completed to scientifically confirm their traditional ethnobotanical uses. Table 5 shows a summary of studies done so far on the plants. The table shows that the majority of the medicinal plants had phytochemicals linked to several of their COVID-19 symptoms alleviation capabilities and had demonstrated some mechanism of action related to COVID-19 treatment pathways. A few medicinal plants had no studies conducted to confirm their use.

\section{Discussion}

This study has demonstrated that there are multiple medicinal plants in Malawi that are being used for disease state management (Additional File 1: Table 1) and that several of these diseases are symptoms associated with COVID-19 (Additional File 2: Table 2). According to the World Health Organization (WHO), patients with mild COVID-19 are recommended to be treated with medicines that manage the presenting symptoms. ${ }^{55}$

The WHO acknowledges that traditional medicines may be sources of new therapies in the search for potential treatments for COVID-19. This is based on the historical integration of medicinal plants into primary healthcare in many areas of the world and on phytochemicals serving as precursor molecules for several commonly used biomedical drugs. ${ }^{55}$ This study was completed as a way of supplementing in the search for therapies for COVID-19 since initial selection of potential plant species for plant-derived lead compounds or medicines stems from ethnobotanical surveys. Since the disease is novel, we could not identify a novel medicinal entity with clinically significant SARS-COV-2 activity. However, plants targeting other viruses and associated symptoms might be repurposed in a similar fashion to various conventional medicines. ${ }^{73}$ However, the WHO warns against the use of traditional medicines without evaluating them first for efficacy, toxicity, and safety. Although WHO recognizes that traditional, complementary and alternative medicines show beneficial effects, and that Africa has a long history of traditional medicine use, medicinal plants can also be toxic and medicinal plants' efficacy may vary due to differences in geographical locations. ${ }^{55,59,73}$

The majority of the 30 medicinal plants identified contained known phytochemicals (Table 4 and 5). The review of the pharmacological effects of the plants confirms why they have potential for testing in the management of COVID-19 patient symptoms and eliminating the virus. The results, for example on Azadrachta indica, are consistent with the results reported by Roy and Bhattacharyya (2020), Shanmuga (2020), as well as Shanmuga et al., (2020) that also showed the potential of this plant in review, computational work, and clinical case study respectively. ${ }^{7476}$ Furthermore, the study results are similar to those of $\mathrm{Li}$ et al who describe the Shufeng Jiedu Capsule/Granule (SFJD) containing eight medicinal herbs in China that is reported to have antiviral, antibacterial, antitumor, and anti-inflammatory activities, and have effective protection against lung injury and neuronal loss achieved through enhancement of autophagy and apoptosis reduction in rats with allergic rhinitis. ${ }^{77}$ It is also reported to improve Pseudomonas aeruginosa-induced upper respiratory tract infection by acting on various targets, particularly ERK phosphorylation. When combined with oseltamivir treatment, SFJD reduced IAV-induced airway inflammation and pulmonary virus titres. This suggests that SFJD may be used for the prevention and treatment of infectious diseases by regulating various signal pathways. ${ }^{77}$

This study can assist WHO's efforts to select traditional medicine products that can be investigated for clinical efficacy and safety in COVID-19. The WHO has historically supported clinical trials of traditional medicine products. https://dx.doi.org/10.4314/mmj.v33i2.4 
Through these previous WHO trials, 89 products have been given market authorisation in 14 countries after meeting international and national requirements for registration. Furthermore, 43 products were included in national essential medicines lists for diseases including malaria, opportunistic infections related to HIV, diabetes, sickle cell disease and hypertension. ${ }^{55}$ This report recommends that the medicinal plants identified be evaluated as potential sources of COVID-19 management remedies and be prioritized for inclusion in clinical and analytical studies for antiviral activity or management of COVID-19 disease.

\section{Conclusions}

Coronaviruses have been in existence for decades and novel strains will continue to emerge. Efforts to find viable, safe and effective treatments in drug discovery pipelines are continuing and will adapt in response to evolving strains. From various community practices across the world, natural products have played a significant role in managing coronavirus related diseases to varying extents. As the aetiology of COVID-19 disease is studied further at the molecular and enzyme levels, a narrower selection can be made for potential hits and leads effective against the disease. Natural products, including plant products, are undoubtedly a promising source of compounds in drug development for possible drug leads and vaccines. It is recommended that multidisciplinary approaches are used to study active phytochemicals with regard to identifying suitable compounds that can be used as they are or developed into possible treatments against Covid-19 and other related coronavirus diseases.

\section{Acknowledgements}

We thank Dr David Scott for assisting with the editing of the paper.

\section{References}

1. Parvez MK, Parveen S. Evolution and Emergence of Pathogenic Viruses: Past, Present, and Future. Intervirology. 2017; 60 (1-2): 1-7.

2. Ball MJ, Lukiw WJ, Kammerman EM, Hill JM. Intracerebral propagation of Alzheimer's disease: strengthening evidence of a herpes simplex virus etiology. Alzheimers Dem. 2013; 9 (2): 169-175.

3. Hober D, Sane F, Jaïdane H, Riedweg K, Goffard A, Desailloud R. Immunology in the clinic review series; focus on type 1 diabetes and viruses: role of antibodies enhancing the infection with Coxsackievirus-B in the pathogenesis of type 1 diabetes. Clin. Exp. Immuno. 2012; 168 (1):47-51.

4. Morgan RL, Baack B, Smith BD, Yartel A, Pitasi M, Falck-Ytter Y. Eradication of hepatitis $\mathrm{C}$ virus infection and the development of hepatocellular carcinoma: a meta-analysis of observational studies. Ann Intern Med. 2013; 158: 329-337.

5. Herrington CS, Coates PJ, Duprex WP. Viruses and disease: emerging concepts for prevention, diagnosis and treatment. J Pathol.2015; 235(2):149-152.

6. Christou L. The global burden of bacterial and viral zoonotic infections. Clin Microbiol Infect.2011; 17(3): 326-330.

7. Cascio A, Bosilkovski M, Rodriguez-Morales AJ, Pappas G. The socio-ecology of zoonotic infections. Clin. Microbiol. Infect. 2011; 17(3): 336-342.

8. Grais RF, Strebel P, Mala P, Watson J, Nandy R, Gayer M. Measles vaccination in humanitarian emergencies: a review of recent practice. Confl. Health. 2011; 5(2):21.

9. Lin CC, Hsu LT, Lin WC. Antiviral natural products and herbal medicines. J. Trad. complement. 2014; 4(1): 24-35.
10. Wang C, Horby PW, Hayden FG, Gao GF. A novel coronavirus outbreak of global health concern.Lancet. 2020; 395(10223): 470473.11. Singhal T. A Review of Coronavirus Disease-2019 (COVID-19). Indian J. Paediat. 2020; 87(4): 281-286.

12. Kim D, Chang H. The architecture of SARS-CoV-2 transcriptome. Cell. 2020; 181(4): 914-921.

13. de Groot RJ, Baker SC, Baric R, Enjuanes L, Gorbalenya AE, Holmes KV. et al. Family Coronaviridae. In King AM, Lefkowitz E, Adams MJ, Carstens EB, International Committee on Taxonomy of Viruses, International Union of Microbiological Societies. Virology Division (eds). 2011, Ninth Report of the International Committee on Taxonomy of Viruses. Oxford: Elsivier., pp. 806-1820.

14. Woo PC, Huang Y, Lau SK, Yuen KY. Coronavirus genomics and bioinformatics analysis. Viruses. 2010; 2(8): 1804-1820.

15. International Committee on Taxonomy of Viruses . (2010-08-24). "ICTV Master Species List 2009—v10".

16. Richman DD, Whitley RJ, Hayden FG. Clinical Virology, 4th ed. Washington : ASM Press, 2016.

17. Yang JL, Ha TKQ, Oh WK. Discovery of inhibitory materials against PEDV corona virus from medicinal plants. The Japanese J. Veteri. Res.2016; 64: 553-563.

18. Xinhua. China's CDC detects a large number of new coronaviruses in the South China seafood market in Wuhan. [Online] 2020. https:// www.xinhuanet.com/2020-01/27/c 1125504355.htm.

19. Kim JM, Chung YS. Jo HJ. Lee NJ. Kim MS. Woo SH. et al. Identification of Coronavirus Isolated from a Patient in Korea with COVID-19. Osong pub. health res. perspect.2020; 11(1): 3-7.

20. Koyama T, Platt D, Parida L. Variant analysis of SARS-CoV-2 genomes. Bulletin of the World Health Organisation. 2020; 98: 495504.

21. Rothe C, Schunk M, Sothmann P, Bretzel G, Froeschl G, Wallrauch C, et al. Transmission of 2019-nCoV Infection from an Asymptomatic Contact in Germany.Engl J Med. 2020; 382(10): 970-971.

22. Zou L, Ruan F, Huang M, Liang L, Huang H, Hong Z, Yu J, Kang M, Song Y, Xia J, Guo Q, Song T, He J, Yen HL, Peiris M, Wu JN. SARS-CoV-2 Viral Load in Upper Respiratory Specimens of Infected Patients. Engl J Med. 2020; 382(12): 1177-1179.

23. Kampf G, Todt D, Pfaender S, Steinmann E. Persistence of coronaviruses on inanimate surfaces and their inactivation with biocidal agents. J. Hosp. Infect. 2020; 104(3): 246-251.

24. World Health Organisation (WHO). Modes of transmission of virus causing COVID-19: Implications for IPC precaution recommendations. [Online] 29 March 2020. https://www.who.int/emergencies/diseases/ novel-coronavirus-2019/situation-reports/. Accessed on 20/09/2020.

25. Cheng ZJ, Shan J. 2019 novel coronavirus: where we are and what we know. Infection. 2020; 48(2): 155-163.

26. Furukawa NW, Brooks JT, Sobel J. Evidence supporting transmission of severe acute respiratory syndrome coronavirus 2 while presymptomatic or asymptomatic. Emerg Infect Dis. 2020; 26(7): e201595.

27. Wark P. Here's what we know so far about the long-term symptoms of COVID-19. The Conversation. July 26, 2020. www.theconversation. com/heres-what-we-know-so-far-about-the-long-term-symptoms-ofcovid-19-142722. Accessed on 20/09/2020.

28. Harvard Medical School. COVID-19 basics; Symptoms, spread and other essential information about the new coronavirus and COVID-19. Harvard Health Publishing 2020. www.health.havard.edu/diseases-andconditions/covid-19-basics. Accessed on 23/09/2020.

29. Dell'Era V, Farri F, Garzaro G, Gatto M, Valletti PA, Garzaro M. Smell and taste disorders during COVID-19 outbreak: A cross-sectional 
study on 355 patients. Head Neck. 2020; 42(7): 1591-1596.

30. Chen N, Zhou M, Dong X, Qu J, Gong F, Han Y. et al. Epidemiological and clinical characteristics of 99 cases of 2019 novel coronavirus pneumonia in Wuhan, China: a descriptive study.Lancet. 2020; 395: 507-513.

31. Panyod S et al. Dietary therapy and herbal medicine for COVID-19 prevention: A review and perspective. Journal of traditional and complementary medicine. 2020; 10(4): 420-427.

32. Beigel JH, Finberg RW, ACTT-1 Study Group Members. Remdesivir for the Treatment of Covid-19 - Preliminary Report. COVID-19 Publications by UMMS Authors. 2020.

33. Jin YH, Cai L, Cheng ZS. et al. A rapid advice guideline for the diagnosis and treatment of 2019 novel coronavirus [2019-nCoV] infected pneumonia [standard version].Mil Med Res. 2020; 7(4).

34. Zhang L, Liu YJ. Potential interventions for novel coronavirus in China: A systematic review. Med. Virol. 2020; 92(5): 479-490.

35. Expert consensus on chloroquine phosphate for the treatment of novel coronavirus pneumonia. Multicenter collaboration group, Department of Science and Technology of Guangdong Province and Health Commission of Guangdong Province, Chloroquine in the treatment of novel corona. Zhonghua Jie He He Hu Xi Za Zhi.2020; 43 (0):E019.

36. Holshue ML, DeBolt C, Lindquist S, Lofy KH, Wiesman J, Bruce H. et al. First Case of 2019 Novel Coronavirus in the United States., Washington State 2019-nCoV Case Investigation Team. Engl. J. Med.2020; 382(10): 929-936.

37. Russell CD, Millar JE, Baillie JK. Clinical evidence does not support corticosteroid treatment for 2019-nCoV lung injury. Lancet. 2020; 395: 473-475.

38. Zhao JP, Hu Y, Du RH. et al. Expert consensus on the use of corticosteroid in patients with $2019-\mathrm{nCoV}$ pneumonia. Zhonghua Jie He He Hu Xi Za Zhi. 2020; 43: E007.

39. Covid-19: Demand for dexamethasone surges as RECOVERY trial publishes preprint. . BMJ. 2020; 369.

40. Aanouz I, Belhassan A, Khatabi KE, Lakhlifi T, Idrissi ME. Bouachrine M. Moroccan Medicinal plants as inhibitors of COVID-19: Computational investigations.J. Biomolec. Structure and Dynam. 2020: 1-9.

41. Soleymani S, Zabihollahi R, Shahbazi S, Bolhassani A. Antiviral effects of saffron and its major ingredients. Curr. Drug Deliv. 2018; 15(5): 698-704

42. Boff L et al. Potential anti-herpes and cytotoxic action of novel semisynthetic digitoxigenin-derivatives. Eur. J. Med. Chem. 2019; 167 546-561.

43. Astani A, Reichling J, Schnitzler P. Screening for antiviral activities of isolated compounds from essential oils. Evid. Based Complement. Alternat. Med. 2011; , 2011.

44. Zhang XR, Kaunda JS, Zhu HT, Wang D, Yang CR, Zhang YJ The Genus Terminalia (Combretaceae): An Ethnopharmacological, Phytochemical and Pharmacological Review. Nat. Prod. Bioprospect.2019; 9: 357-392.

45. Luo H, Tang Q, Shang Y et al. Can Chinese Medicine Be Used for Prevention of Corona Virus Disease 2019 (COVID-19)? A Review of Historical Classics, Research Evidence and Current Prevention Programs. Chinese J. Integ. Med. 2020; 26: 243-250.

46. Xiong X, Wang P, Su K, Cho WC, Xing Y. Chinese herbal medicine for coronavirus disease 2019: A systematic review and meta-analysis. Pharmacological research. 2020; 160(105056).

47. Li SY, Chen C, Zhang HQ, Guo HY, Wang H, Wang L. et al. Identification of natural compounds with antiviral activities against SARS-associated coronavirus. Antiviral research. 2005; 67(1): 18-23.
48. Yu MS, Lee J, Lee JM, et al. Identification of myricetin and scutellarein as novel chemical inhibitors of the SARS coronavirus helicase, nsP13. Bioorg Med Chem Lett. 2012; 22(12): 4049-4054.

49. Mani JS, Johnson JB, Steel JC, et al. Natural product-derived phytochemicals as potential agents against coronaviruses: A review. Virus Res. 2020; 284: 197989. doi:10.1016/j.virusres.2020.197989, Vol. 284.

50. Ryu YB., Jeong HJ, Kim JH, Kim YM, Park JY, Kim D. et al. Biflavonoids from Torreya nucifera displaying SARS-CoV 3CL (pro) inhibition.Bioorg. Med. Chem. 2010; 18(22): 7940-7947.

51. Lau KM, Lee KM, Koon CM, Cheung CS, Lau CP, Ho HM. et al. Immunomodulatory and anti-SARS activities of Houttuynia cordata. J. ethnopharm. 2008; 118(1): 79-85.

52. Wang Z, Chen X, Lu Y, Chen F, Zhang W. Clinical characteristics and therapeutic procedure for four cases with 2019 novel coronavirus pneumonia receiving combined Chinese and Western medicine treatment. BioSci. Trends.2020; 14(1): 64-68.

53. Oyebode O, Kandala NB, Chilton PJ, Lilford RJ. Use of traditional medicine in middle-income countries: a WHO-SAGE study. Health Policy Plan.2016; 31(8): 984-991.

54. Zhang D, Wu K, Zhang X, Deng S, Peng B. In silico screening of Chinese herbal medicines with the potential to directly inhibit 2019 novel coronavirus. J. Integ. Med. 2020; 18(1):152-158.

55. World Health Organisation (WHO). WHO supports scientificallyproven traditional medicine. 2020. www.afro.who.int/news/who-supp. Accessed on 25/07/2020

56.Loayza NV. Costs and Trade-Offs in the fight against the COVID-19 Pandemic: A Developing Country Perspective (English). Research and Policy Briefs. Washington DC : World Bank Group, 2020.

57. Gadabu A. Malawi's Response, Risk Factors, and Preparedness for COVID-19. North American Academic Research -NAAR. 20203(4): http://doi.org/10.5281/zenodo.3732795.

58. Rajagopal D. Hydroxychloroquine becomes a Schedule H1 drug as hoarding leads to shortage. Economics Times. Mar 27 2020. www. economictmes.com/industry/healthcare/biotech/pharmaceuticals/ hydroxychloroqine-becomes-a-schedule-h1-drug-as-hoarding-leadsto-shortage/articlesshow/74842650.cms.

59. Nafiu MO, Hamid AA, Muritala HF Adeyemi SB. Chapter 7 Preparation, Standardization, and Quality Control of Medicinal Plants in Africa. 2017. in: Medicinal Spices and Vegetables from Africa. 2017: 171-204.

60. Chikowe I, Mnyenyembe M, Jere S, Mtewa AG, Mponda J, Lampiao F. An ethnomedicinal survey of indigenous knowledge on medicinal plants in the traditional authority Chikowi in Zomba, Malawi. Current Traditional Medicine.2020; 5(1).

61. Mwafongo E, Nordal I, Magombo Z, Stedje B. Ethnobotanical study of Hyacinthaceae and non-hyacinthaceous geophytes in selected districts of Malawi. . Ethnobot. Res. Appl. 2010; 8: 75-93.

62. Robinson L, Sclar D, Scaer T. Medicinal Plant Use by Traditional Healers in Malawi: Focus on Neem, Tephrosia, Moringa, Jatropha, Marula and Natal Mahogany. Malawi Agroforestry Extension Project. 2002: 11-18.

63. Saka JD, Msonthi JD. Nutritional value of edible fruits of indigenous wild trees in Malawi.For. Ecol. Manage.1994; 64: 245-248.

64. Manda L. Status and uses of Oldfieldia dactylophylla (Euphorbiaceae) in Malawi. Uppsala : CBM Master Theses No. 38. Swedish Biodiversity Centre (CBM), SLU, Box 7007, SE-750 07. 2007; Uppsala, Sweden.

65. Maliwichi-Nyirenda CP, Maliwichi LL. Medicinal plants used for contraception and pregnancy-related cases in Malawi: A case study of Mulanje District.Journal of Medicinal Plants Research. 2010; 4(20):3024-3030.

66. Gordon CN. People and protected areas: Natural resource https://dx.doi.org/10.4314/mmj.v33i2.4 
harvesting as an approach to support rural communities surrounding Majete Wildlife Reserve, Southern Malawi. Capetown : Masters thesis. Stellenbosch University, South Africa. 2017.

67. Bundschuh TV, Hahn K, Wittig R. The Medicinal Plants of the Woodlands in northern Malawi (Karonga District). Flora et Vegetatio Sudano-Sambesica.2011; 14: 3-8.

68.Maliwichi-Nyirenda CP. The conservation biology of Berberis holstii engl. in Nyika national park, Malawi. Plymouth : University of Plymouth Research Theses. 2008.

69. Kayambazinthu D, Barany M, Mumba R, Anyonge CH. Miombo woodlands and HIV/AIDS interactions: Malawi Country Report. Food and Agriculture Organization of the United Nations. Forestry Policy and Institutions Working Paper 6. Rome : FAO, 2005.

70.Chisaka JW. The use of traditional herbal medicines among palliative care patients at Mulanje Mission Hospital, Malawi. Capetown : Faculty of Health Sciences, Department of Public Health and Family Medicine, University of Capetown.2019. .

71. Mei Y, Yang B. Rational application of drug promiscuity in medicinal chemistry. Future medicinal chemistry. 2018; 10(15).

72. Parasuraman S, Thing GS, Dhanaraj SA. Polyherbal formulation: Concept of ayurveda. Pharmacogn. Rev. 2014; 8(16): 73-80.

73. Yang Y. Use of herbal drugs to treat COVID-19 should be with caution. The Lancet. 2020; 395(10238): 395.

74. Roy S, Bhattacharyya P. Possible role of traditional medicinal plant Neem (Azadirachta indica) for the management of COVID-19 infection. International Journal of Research in Pharmaceutical Sciences..2020; 11(SPL1): 122-125.

75. Shanmuga SS. Some Compounds from Neem leaves extract exhibit binding affirnity as high as $-14.3 \mathrm{kcal} / \mathrm{mol}$ against COVID-19 Main Protease (Mpro): A Molecular Docking Study. Molecular Biology.2020. DOI: $10.21203 /$ rs.3.rs.2564/v1.

76. Shanmuga SS, Kanitkar PM, Neeta, Shirish K. Neem (Azadirachta Indica) leaves in the treatment of COVID19/SARS-CoV-2 : A Case Report. Figshare. 2020; Figshare. Preprint.

77. Li C, Wang L, Ren L. Antiviral mechanisms of candidate chemical medicines and traditional Chinese medicines for SARS-CoV-2 infection [published online ahead of print, 2020 Jun 24].Virus Res.2020; 286(198073).

78. Ramadass N, Subramanian N. Study of phytochemical screening of neem (Azadirachta indica). Int. J. Zoo. Studies.2018; 3(1): 209-212.

79. Dash SP, Dixit S, Sahoo S. Phytochemical and Biochemical Characterizations from Leaf Extracts from Azadirachta Indica: An Important Medicinal Plant. Biochem. Anal. Biochem.2017; 6(323).

80. Arora R, Chawla R, Marwah R, et al. Potential of Complementary and Alternative Medicine in Preventive Management of Novel H1N1 Flu (Swine Flu) Pandemic: Thwarting Potential Disasters in the Bud. Evid Based Complement Alternat Med. 2011; 2011.

81. Bhowmik D, Chiranjib, Yadav J, Tripathi KK, Kumar KPS. Herbal Remedies of Azadirachta indica and its Medicinal Application. J. Chem. Pharm. Res. 2010; 2(1): 62-72.

82. Hannan A, Khan SA, Choudhry et al. Antibacterial activity of Neem (Azadirachta indica) leaf extracts against wound causing bacteria. Healthmed. 2014; 8(6): 767-773.

83. Lakshmi T, Krishnan V, Rajendran R, Madhusudhanan N. Azadirachta indica: A herbal panacea in dentistry - An update. Pharmacogn. Rev. 2015; 9(17): 41-44.

84. Alzohairy MA. Therapeutics Role of Azadirachta indica (Neem) and Their Active Constituents in Diseases Prevention and Treatment. Evid Based Complement. Alternat. Med.2016; 2016.

85. Connelly MP, Fabiano E, Patel IH, Kinyanjui SM, Mberu EK, Watkins WM. Antimalarial activity in crude extracts of Malawian medicinal plants. Ann Trop Med Parasitol. 1996; 90(6): 597-602.

86. Maroyi A. Azanza garckeana Fruit Tree: Phytochemistry, Pharmacology, Nutritional and Primary Healthcare Applications as Herbal Medicine: A Review. Res. J. Med. Plants. 2017; 11: 115-123.

87. Yusuf AA, Lawal B, Sani S. et al. Pharmacological activities of Azanza garckeana (Goron Tula) grown in Nigeria. Clin. Phytosci. 2020; 6: 27 .

88. Srivastava S, Srivastava M, Misra A, Pandey G, Rawat A. A review on biological and chemical diversity in Berberis (Berberidaceae). EXCLI J. 2015; 14: 247-267.

89. Kimani NL, Njangiru IK, Njagi ENM, Orinda GO. Antidiabetic activity of administration of aqueous extract of Berberis holstii. 11, 2017, J. Diabetes Metab., Vol. 8.

90. Pathy K. The Influenza a Virus Subtypes H1N1, H1N2 and H3N2, HDFx: A Novel Immunomodulator and Potential Fighter Against Cytokine Storms in Viral Flu Infections- Carica Papaya Linn. Int. J. clin. Case. 2017; 1(8): 159-165.

91. Saeed F, Arshad MU, Pasha I, Naz R, Batool R, Khan AA, et al. Nutritional and Phyto-Therapeutic Potential of Papaya (Carica Papaya Linn.): An Overview. International Journal of Food Properties.2014; 17(7): 1637-1653.

92. Ahmad N, Fazal H, Ayaz M, Abbasi BH, Mohammad I, Fazal L. Dengue fever treatment with Carica papaya leaves extracts. Asian Pac. J. Trop. Biomed. 2011; 1(4): 330-333.

93. Srikanth BK, Reddy L, Biradar S, Shamanna M, Mariguddi DD, Krishnakumar M. An open-label, randomized prospective study to evaluate the efficacy and safety of Carica papaya leaf extract for thrombocytopenia associated with dengue fever in pediatric subjects. Pediatric Health Med. Ther. 2019; 10: 5-11.

94. Priyadarshi A, Ram B. A review on pharmacognosy, phytochemistry and pharmacological activity of Carica papaya (linn) leaf. Int J Pharm Sci \& Res.2018; 9(10): 4071-78.

95. Bhatnagar S, Sahoo S, Mohapatra AK, Behera DR. Phytochemical analysis, Antioxidant and Cytotoxic activity of medicinal plant Combretum roxburghii (Family: Combretaceae). Int. J. Drug Dev. \& Res.2012; 4(1): 193-202.

96. de Morais LGR, de Sales IRP, Caldas FMRD, et al. Bioactivities of the genus Combretum (Combretaceae): A review. Molecules. 2012; 17: 9142-206.

97. Makhafola TJ, Elgorashi EE, McGaw LJ, Awouafack MD, Verschaeve L, Eloff JN. Isolation and characterization of the compounds responsible for the antimutagenic activity of Combretum microphyllum (Combretaceae) leaf extracts. BMC Complement Altern Med. 2017; 17(1): 446.

98. Maroyi A. Dicoma anomala sond: A review of its botany, ethnomedicine, phytochemistry and pharmacology. Asian J. Pharmaceut. Clin. Res. 2018; 11(6): 70.

99. Eramma N, Gayathri D. Antibacterial potential and phytochemical analysis of Flacourtia indica (Burm.f.) Merr. root extract against human pathogens. Indo American J. Pharmaceut. Res. 2013; 3: 3832-46.

100. Adesina et al.Plants in Respiratory Disorders II- Antitussives, A Review.BJPR. 2017; 16(3): 1-21.

101. Sunday B, Atawodi E, Olowoniyi OD. Pharmacological and Therapeutic Activities of Kigelia africana (Lam.). Ann. Res. Rev. Bio.2015; 1: 1-17.

102. Singh L, Singh J, Singh J. Medicinal and Nutritional Values of Drumstick Tree (Moringa oleifera):A Review. Int.J.Curr.Microbiol. App.Sci.2019; 8(05): 1965-1974.

103. Asnaashari S, Dastmalchi S, Javadzadeh Y. Gastroprotective effects of herbal medicines (roots). Int. J. Food Prop. 2018; 21(1):902920. 
104. Oko AO, Ekigbo JC, Idenyi JN. Nutritional and Phytochemical Compositions of the Leaves of Mucuna Poggei. J. Bio. Life Sci. 2012; 3(1): 232 .

105. Vongtau H, Amos S, Hohn-Africa LB. Pharmacological effects of the aqueous extract of Neorautanenia mitis in rodents. Journal of Ethnopharmacology. 2000; 72(1-2): 207-14.

106. Dawurung CJ, Gotep JG, Usman JG, Elisha IL, Lombin LH, Pyne SG. Antidiarrheal activity of some selected Nigerian plants used in traditional medicine. Phcog. Res. [serial online]. 2019; 11:371-7.

107. Afolayan M, Srivedavyasasri R, Asekun OT, Familoni OB, Orishadipe A, Zulfiqar F. et al. Phytochemical study of Piliostigma thonningii, a medicinal plant grown in Nigeria. Med. Chem. Res.2018; 27: 2325-2330.

108. Omolo JJ, Maharaj V, Naidoo D, Klimkait T, Malebo HM, Mtullu S, Lyaruu HM, de Koning CB. Bioassay-Guided Investigation of the Tanzanian Plant Pyrenacantha kaurabassana for Potential Anti-HIVActive Compounds. J. Nat. Prod. 2012; 75(10): 1712-1716.

109. Russo D, Kenny O, Smyth T, Milella L, Hossain M, Diop M, Rai D, Brunton N. Profiling of Phytochemicals in Tissues from Sclerocarya birrea by HPLC-MS and Their Link with Antioxidant Activity.ISRN Chromatography. 2013: 1-11.

110. John AO, Ojewole, Mawoza T, Witness DH, Chiwororo, Peter MO. Sclerocarya birrea (A. Rich) Hochst. ['Marula'] (Anacardiaceae): A Review of its Phytochemistry, Pharmacology and Toxicology and its Ethnomedicinal Uses. Phytother. Res.2010; 24: 633-639.

111. Pallant CA, Cromarty AD, Steenkamp V. Effect of an alkaloidal fraction of Tabernaemontana elegans (Stapf.) on selected microorganisms.J Ethnopharmacol.2012; 140(2): 398-404.

112. Hapsari BW, Martin AF, Maulana E, Ermayanti TM. Growth, phytochemical properties, and antioxidant activity of in vitro-gamma irradiated Tacca leontopetaloides (L.) Kuntze. AIP Conference Proceedings. 2019; 2199.

113. Mkindi AG, Tembo Y, Mbega ER, et al. Phytochemical Analysis of Tephrosia vogelii across East Africa Reveals Three Chemotypes that Influence Its Use as a Pesticidal Plant.Plants (Basel). 2019; 8(12): 597.

114. Yadeta NC, Tessema SS. Phytochemical Investigation and characterisation of the chemical cosntituents from root extracts of Tephrosia vogelli. International Journal of Novel Research in Engineering and Science. 2019; 6(2): 1-14.

115. Mongaloa NI, McGawa LJ, Segapelod TV, Finniea JF, Van Staden VJ. Ethnobotany, phytochemistry, toxicology and pharmacological properties of Terminalia sericea Burch. ex DC. (Combretaceae) - A review. J. Ethnopharm. 2016; 194: 789-802.
116. Viol DI. Screening of traditional medicinal plants from Zimbabwe for phytochemistry, antioxidant, antimicrobial, antiviral and toxicological activities. School of Pharmacy, College of Health Sciences, University of Zimbabwe Thesis. 2009.

117.Cock IE.The medicinal properties and phytochemistry of plants of the genus Terminalia (Combretaceae). Inflammopharmacol.2015; 23(5): 203-29.

118. Konate K, Yomalan K, Sytar O, Brestic M. Antidiarrheal and antimicrobial profiles extracts of the leaves from Trichilia emetica Vahl. (Meliaceae)KK. Asian Pacific Journal of Tropical Biomedicine.2015; 5(3): 242-248.

119. Brigitte KML, Flaurant TT, Emmanuel T. Antimicrobial, Antioxidant and Protective Effect of Methanol Extract of Trichilia emetica (Meliaceae) Stem and Root Bark against Free Radical-induced Oxidative Haemolysis. EJMP [Internet].2017; 19(1): 1-4.

120. Maroyi A. Zanha africana (Radlk.) Exell: review of its botany, medicinal uses and biological activities. Pharm. Sci. \& Res.2019; 11(8): 2980-2985.

121. Bode AM, Dong Z. Chapter 7. The Amazing and Mighty Ginger. In: Benzie IFF, Wachtel-Galor S, eds. Herbal Medicine: Biomolecular and Clinical Aspects. 2nd edition. Boca Raton (FL): CRC Press/Taylor \& Francis; 2011. Available from: https://www.ncbi.

122. Chang JS, Wang KC, FengYeh CF, Shieh DE, Chiang LC. Fresh ginger (Zingiber officinale) has anti-viral activity against human respiratory syncytial virus in human respiratory tract cell lines. Journal of Ethnopharmacology. 2013; 145(1): 146-151.

123. Koh EM, Kim HJ, Kim S, eds. et al. Modulation of macrophage functions by compounds isolated from Zingiber officinale. Planta Med. 2009; 75(2): 148-51.

124. de Groot RJ, Baker SC, Baric RS, et al. Middle East respiratory syndrome coronavirus (MERS-CoV): announcement of the Coronavirus Study Group. J Virol. 2013; 87(14): 7790-7792. 
Table 1: List of Medicinal Plants that were included in the study

\begin{tabular}{|c|c|c|}
\hline Abrus precatorius & Cissus zombensis Gilg and Brandt & Grewia bicolor \\
\hline Acacia adenocalyx & Clerodendrum glabrum & Grewia flavenscens \\
\hline Acacia amythethophylla & Cocculus hirsuitus & Grewia inaequilatera \\
\hline Acacia nilotica & Coffea swynnertonii & Grewia micrantha \\
\hline Acacia sieberana & Colocasia esculenta (L.) Schott & Grewia stolzii \\
\hline Acacia sp. & Combretum apiculatum & Habenaria sp. \\
\hline Acalypha chirindica & Combretum fragrans & Heteromorpha trifoliata \\
\hline Acalypha villicaulis & Combretum microphyllum & Hibiscus cannabinu L. \\
\hline Adenia gummifera (Harv.) Harms & Combretum mossambicense & Hippocratea parviflora \\
\hline Aeschynomene abyssinica & Commiphora mossambicensis & Holarrhena pubescens \\
\hline Aframomum angustifolia & Cordyla africana & Hymenocardia acida Tul. \\
\hline Afzelia quanzensis Welw. & Crinum macowanii Baker & Hymenodictyon floribundum \\
\hline Ageratum houstonia (compsitae) & Crossopteryx febrifuga & Hymenodictyon parvifolium \\
\hline Albizia harveyi & Cryptolepis obtusa & Hypoxis villosa L.f. \\
\hline Albuca abyssinica Jacq. & Cucumis hirsutus Sond. & Indigofera emarginella \\
\hline Algae spp. & Cyphostema ssp. & Inula glomerata \\
\hline Allium sativum & Cyphostemma junceum & Jateorhiza bukobensis \\
\hline Allophylus chaunostachys & (Webb) Desc. ex Wild & jatropha curcas \\
\hline Aloe swynnertonii & \& R.B. Drumm. & Julbernardia globiflora \\
\hline Aloe vera & Cyphostemma setosum & Kaempferia rosea Schweinf. ex \\
\hline Ampelocissus africana & Cyphostemma zombense & Baker \\
\hline Ampelocissus obtusata (Welw. ex & Dalbergia melanoxylon & Khaya nyasica or Khaya \\
\hline Baker) Planch. & Dalbergia nitidula & anthotheca \\
\hline Annona senegalensis & Dalbergiella nyassae & Kigelia africana \\
\hline Anthospermum spec. & Dichrostachys cinerea & Kirkia acuminata \\
\hline Apodytes dimidiata & Dicoma amoena & Lagenaria sphaerica \\
\hline Aristolochia hockii & Dioscorea bulbifera L. & Lannea discolor \\
\hline Asparagus setaceus & Dioscorea dumetorum (Kunth) Pax & Lannea edulis \\
\hline Azadrachta indica & Dioscorea esculenta (Lour.) & Lecaniodiscus fraxinifolius \\
\hline Azanza garckeana & Burkill & Ledebouria cordifolia (Baker) \\
\hline Azedaracht indica & Dioscorea odoratissima Pax & Stedje \& Thulin \\
\hline Bauhinia petersiana & Dioscorea sansibarensis $\mathrm{Pax}$ & Ledebouria revolute (L.f.) Jessop \\
\hline Bauhinia thonningii & Diospyros kirkii & Leersia hexandra \\
\hline Berberis holstii & Diospyros zombensis & Leonotis nepetifolia \\
\hline Bersama abyssinca & Diplorhynchus condylocarpon & Maerua parvifolia \\
\hline Boophone disticha (L.f.) & Disa sp. & Mangifera indica \\
\hline Borassus aethiopum & Dolichos kilimandscharicus & Manihot glaziovii Müll. Arg. \\
\hline Boscia salicifolia Oliv & Dolichos trinervatus Baker & Margaritaria discoidea or \\
\hline Brachystegia allenii Hutch. \& & Dombeya acutangula & Phyllanthus discoideus \\
\hline Burtt Davy & Dychrostachys cincerea & Markhamia obtusifalia \\
\hline Breonadia microcephala (Del.) & Ehretia amoena & Maunkhalamba \\
\hline Bridelia cathartica G. Bertol. & Ehretia divaricata & Maytenus heterophylla or \\
\hline Byrsocarpus orientalis (Baill.) & Ehretia obtusifolia & Gymnosporia buxifolia \\
\hline Bak. & Ekebergia benguelensis Welw. ex & Maytenus senegalensis or $G$. \\
\hline Calotropis procera & Elephantorrhiza goetzei & senegalensis \\
\hline Canthium glaucum ssp. & Elytaria lyrata & Melia azedarach \\
\hline Carica papaya & Eminia antennulifera (Baker) Taub & Momordica foetida Schumach \& \\
\hline Cassia abbreviata & Eriospermum abyssinicum Baker & Thonn. \\
\hline Cassipourea mollis & Erythrophleum suaveolens & Mondia whitei \\
\hline Cassytha filiformis $\mathrm{L}$. & Euphorbia hirta & Monodora junodii \\
\hline Catunaregam spinosa & Euphorbia matabelensis & Molinga oleifera \\
\hline Cissus aristolochiifolia Planch & Ficus capensis Thunb. & Mucuna poggei Taub. \\
\hline Cissus cornifolia & Ficus kirkii Hutch. & Multidentia crassa \\
\hline Cissus faucicola & Ficus natalensis & Musa paradisiaca $\mathrm{L}$. \\
\hline Cissus integrifolia & Ficus sycomorus & Neorautanenia mitis (A.Rich.) \\
\hline Cissus quadrangularis & Flacourtia indica & Verdc. \\
\hline Cissus rubiginosa (Welw.ex & Frueggea virosa & Nidorella auricalata \\
\hline Baker) Planch & Gladiolus dalenii Van Geel & Nymphaea caerulea Savigny \\
\hline Cissus sp. & Gloriosa superba L. goetzei & Terminalia kaiseriana \\
\hline
\end{tabular}


Table 1 Cont....

\begin{tabular}{|c|c|c|}
\hline $\begin{array}{l}\text { Cissus votundifolia } \\
\text { Ocimum americanum } \\
\text { Olax dissitiflora } \\
\text { Olax obtusifolia } \\
\text { Oldfieldia dactylophylla } \\
\text { Ormocarpum kirkii } \\
\text { Ozoroa reticulata } \\
\text { Paederia bojerana } \\
\text { Parinari excelsa } \\
\text { Passiflora edulis } \\
\text { Paulozia mixta } \\
\text { Pericopsis angolensis } \\
\text { Phelinus gilvus } \\
\text { Philenoptera capassa } \\
\text { Philenoptera violacea } \\
\text { Phyllanthus ovalifolius } \\
\text { Phyllanthus reticulatus } \\
\text { Piliostigma thonningii } \\
\text { Plectranthus esculentus } \mathrm{N} . \mathrm{E} . \text { Br } \\
\text { Popowia obovata or Friesodielsia } \\
\text { obovata } \\
\text { Portulaca oleracea L. } \\
\text { Pouzolzia mixta } \\
\text { Protea petiolaris } \\
\text { Pseudarthria hookeri } \\
\text { Pseudolachnostylis maprouneifolia } \\
\text { Psidium guajava } \\
\text { Psorospermum febrifugum } \\
\text { Pterocarpus angolesis } \\
\text { Pterocarpus brenanii } \\
\text { Pupalia lappacea } \\
\text { Pyrenacantha kaurabassana }\end{array}$ & $\begin{array}{l}\text { Gonatopus boivinii (Decne.) Engl. } \\
\text { Raphionacme welwitschii Schltr. \& } \\
\text { Rendle } \\
\text { Rhus longipes } \\
\text { Rhus natalensis } \\
\text { Ricinus communis } \\
\text { Rothmannia fischeri } \\
\text { Rytigynia adenodonta or Rytigynia } \\
\text { reticulata } \\
\text { Rytigynia monantha } \\
\text { Sclerocarya birrea } \\
\text { Sclerocarya caffra } \\
\text { Searsia tenuinervis } \\
\text { Securidaca longepedunculata } \\
\text { Senna siamea or Cassia siamea } \\
\text { Smilax anceps } \\
\text { Solanum anguivii } \\
\text { Solanum panduriforme } \\
\text { Sphaeranthes angolensis } \\
\text { Sphenostylis emarginata } \\
\text { Steganotaenia araliacea } \\
\text { Sterculia quinqueloba } \\
\text { Stereospermum kunthianum } \\
\text { Strophanthus kombe } \\
\text { Strychnos madagascariensis } \\
\text { Stylochiton puberulus N.E.Br. } \\
\text { Tabernaemontana elegans } \\
\text { Tacca leontopetaloides } \\
\text { Tamarindus indica } \\
\text { Tephrosia vogeli }\end{array}$ & $\begin{array}{l}\text { Terminalia mollis } \\
\text { Terminalia sericea } \\
\text { Terminalia stenostachya } \\
\text { Tragia brevipes } \\
\text { Tricalysia coriacea } \\
\text { Tricalysia spp. } \\
\text { Trichillia emetica } \\
\text { Trichodesma zeylanicum } \\
\text { Tricliceras longepedunculatum } \\
\text { Turraea floribunda } \\
\text { Turraea nilotica } \\
\text { Tylosema fassoglensis (Kotschy ex } \\
\text { Schweinf.) Torre \& Hillc. } \\
\text { Vangueria infausta } \\
\text { Vernonia adoensis } \\
\text { Vernonia colorata } \\
\text { Vigna radiata } \\
\text { Vigna subterranean } \\
\text { Vitex doniana } \\
\text { Vitex mombassae } \\
\text { Vitex payos } \\
\text { Xeroderris stuhlmannii (Taub.) } \\
\text { Mendonca \& EP Sousa. } \\
\text { Ximenia americana L. } \\
\text { Ximenia caffra } \\
\text { Zanha africana } \\
\text { Zingiber officinale } \\
\text { Ziziphus abyssinica }\end{array}$ \\
\hline
\end{tabular}


Table 2: List of Medicinal Plants that were evaluated further for Pharmacological and Physicochemical Properties

\begin{tabular}{|c|c|}
\hline Abrus precatorious & Dicoma anomala Sond. \\
\hline Acacia macrothyrsa & Dicoma kirkii \\
\hline Acalypha chirindica & Dioscorea bulbifera $\mathrm{L}$. \\
\hline Aerva leucura & Diplorhynchus condylocarpon \\
\hline Aeschynomene abyssinica & Dolichos kilimandscharicus \\
\hline Aeschynomene nyassana & Dolichos trinervatus Baker \\
\hline Afzelia quanzensis & Ectadiopsis oblongifolia \\
\hline Ageratum houstonia (compsitae) & Ehretia amoena klotzschi \\
\hline Albizia zimmermanii & Ehretia divaricata \\
\hline Albuca abyssinica Jacq. & Ehretia obtusifolia \\
\hline Algae spp. & Elephantorrhiza goetzei \\
\hline Allium sativum & Eriospermum abyssinicum Baker \\
\hline Aloe spp. & Erythrophleum sauveolens \\
\hline Aloe swynnertonii & Fagara chalybea \\
\hline Aloe vera & Ficus capensis \\
\hline Ampelocissus Africana (Lour.) Merr. & Flacourtia indica \\
\hline Annona senegalensis & Flueggea virosa, Securinega virosa \\
\hline Azanza garckeana & Gonatopus boivinii (Decne.) Engl. \\
\hline Azedarachta indica & Grewia micrantha \\
\hline Bauhinia thonningii & Heteromorpha arborescens \\
\hline Berberis holstii & Holarrhena pubescens \\
\hline Boophone disticha (L.f.) & Hymenocardia acida \\
\hline Brachystegia utilis & Hypoxis villosa L.f. \\
\hline Breonadia microcephala & Ipomoea tenuirostris \\
\hline Bridelia micrantha & Jatropha curcas \\
\hline Burkea africana & Kaempferia rosea Schweinf. ex Baker \\
\hline Capsicum frutescens & Kigelia africana \\
\hline Carica papaya & Lannea edulis \\
\hline Carissa edulis & Lotus sp. \\
\hline Cassia abbreviata & Markhamia obtusifolia \\
\hline Ceiba pentandra & Melia azedarach \\
\hline Cissampelos mucronata & Momordica foetida Schumach \& Thonn. \\
\hline Cissus quadrangularis & Moringa oleifera \\
\hline Cissus rubiginosa (Welw.ex Baker) Planch. & Mucuna poggei Taub. \\
\hline Cissus zombensis (Baker) Gilg \& M. Brandt & Multidentia crassa \\
\hline Combretum microphyllum & Musa paradisiaca \\
\hline Corchorus trilocularis & Neorautanenia mitis (A.Rich.) Verdc. \\
\hline Cordyla africana & Nidorella auricalata \\
\hline Crinum macowanii Baker & Oldfieldia dactylophylla \\
\hline Croton megalobostrys & Parinari excelsa Sabine \\
\hline Cussonia arborea & Pericopsis angolensis \\
\hline Cyphostema spp. & Phelinus gilvus \\
\hline Cyphostemma junceum (Webb) & Phyllanthus reticulatus \\
\hline Dalbergia nyassae, Swartzia madagascariensis & Piliostigma thonningii \\
\hline
\end{tabular}


Table 2 Cont....

\begin{tabular}{|l|l|}
\hline Dichrostachys cinerea & Pseudolachnostylis maprouneifolia \\
Psorospermum febrifugum & Tricalysia coriacea \\
Pterocarpus angolensis & Tricalysia spp. \\
Pyrenacantha kaurabassana Baill. & Trichillia emetica \\
Rauvolfia caffra & Trichodesma zeylanicum \\
Rhus longipes & Turraea floribunda \\
Rothmannia fischeri & Turraea nilotica \\
Schrebera trichocloclada & Tylosema fassoglensis (Kotschy ex Schweinf.) \\
Sclerocarya birrea & Torre \& Hillc. \\
Searsia tenuinervis & Uapaca kirkiana \\
Senna petersiana & Vernonia corolata \\
Senna sengueana & Vigna radiata \\
Sphaeranthes angolensis & Vitex mombassae \\
Steganotaenia araliacea & Xeroderris stuhlmannii (Taub.) Mendonca \& \\
Strychnos innocua & EP Sousa. \\
Tabernaemontana elegans & Ximenia americana \\
Tacca leontopetaloides (L.) Kuntze & Ximenia caffra \\
Tephrosia vogeli & Xylopia perviflora \\
Terminalia sericea & Zanha africana \\
Thunbergia spp. & Zingiber officinale \\
\hline
\end{tabular}


Table 3: Number of plants found to be used for each of the COVID-19 related diseases or symptoms

\begin{tabular}{|c|c|c|}
\hline Variable & Frequency $n=306$ & Percentage \\
\hline Cough & 11 & 3.59 \\
\hline Pneumonia & 9 & 2.94 \\
\hline Breath/Asthma & 5 & 1.63 \\
\hline Pain/Aches & 87 & 28.43 \\
\hline Fever & 2 & 0.65 \\
\hline Diarrhoea & 1 & 0.33 \\
\hline Immunity & 8 & 2.61 \\
\hline Blood & 10 & 3.27 \\
\hline Fatigue & 2 & 0.65 \\
\hline Heart & 11 & 3.95 \\
\hline Viral Activity & 12 & 3.92 \\
\hline Inflammation & 8 & 2.61 \\
\hline Rheumatism & 10 & 3.27 \\
\hline
\end{tabular}


Table 4: Medicinal plants used on more than one COVID-19 related disease

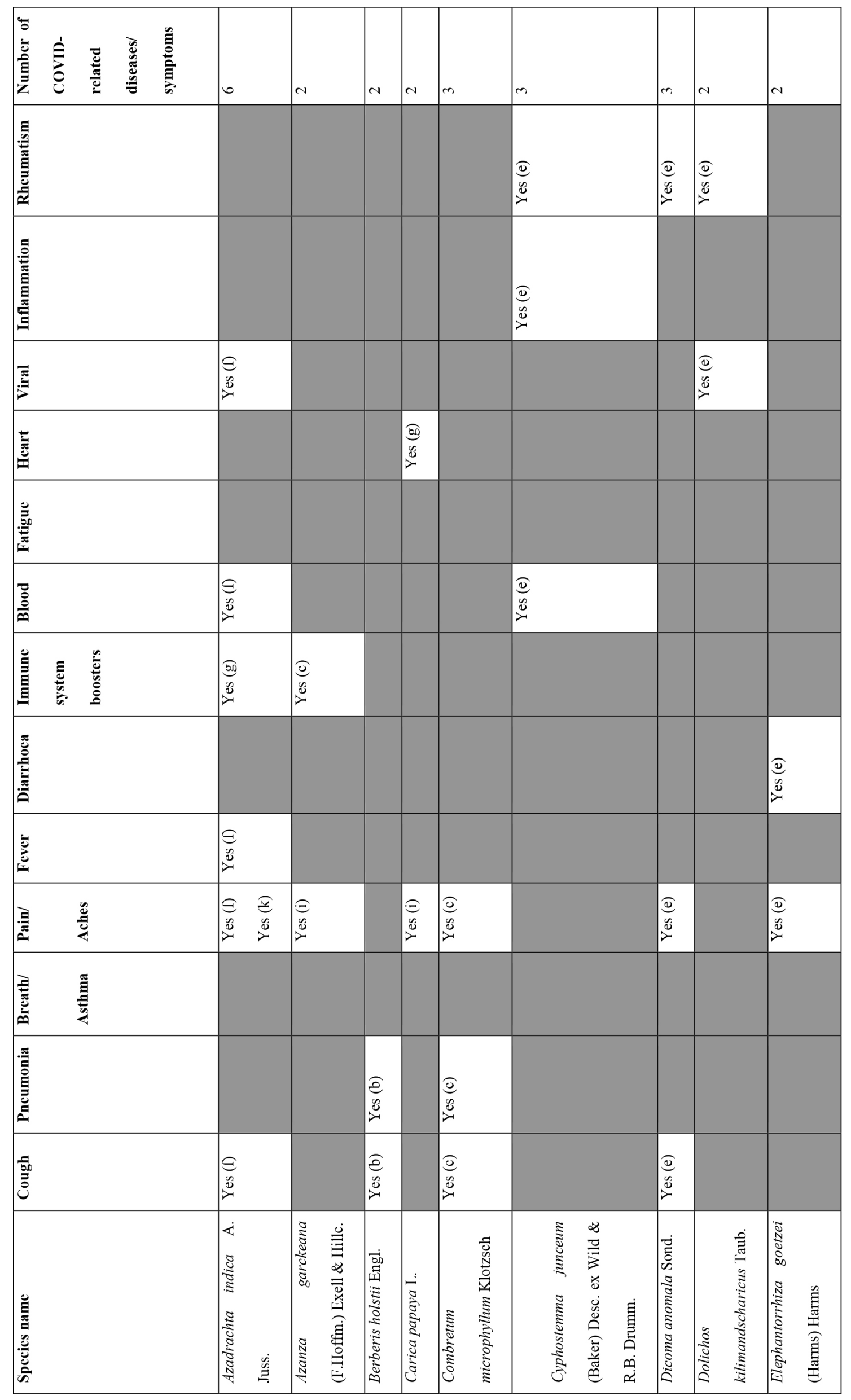




\section{Table 4 Cont....}

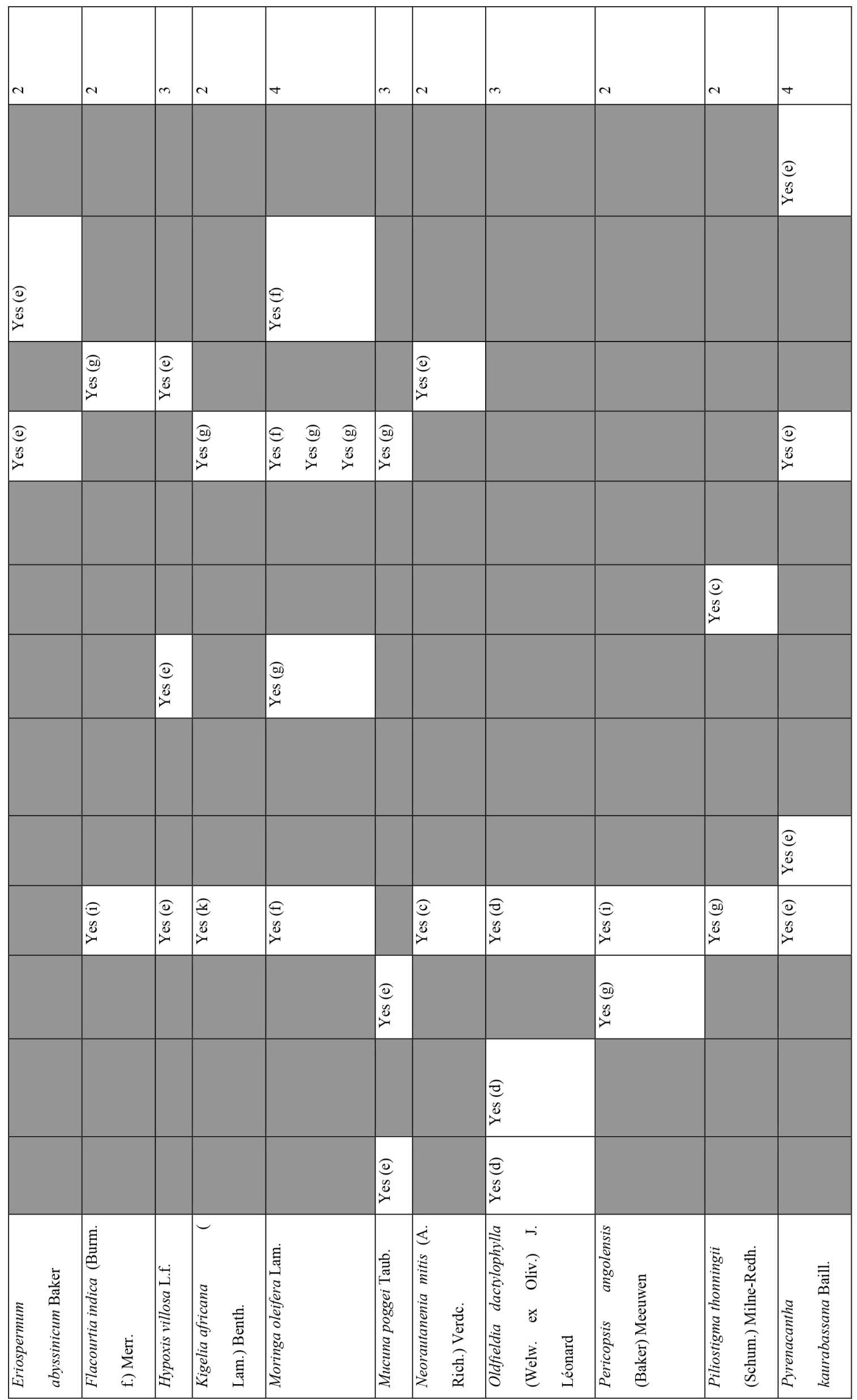




\section{Table 4 Cont....}

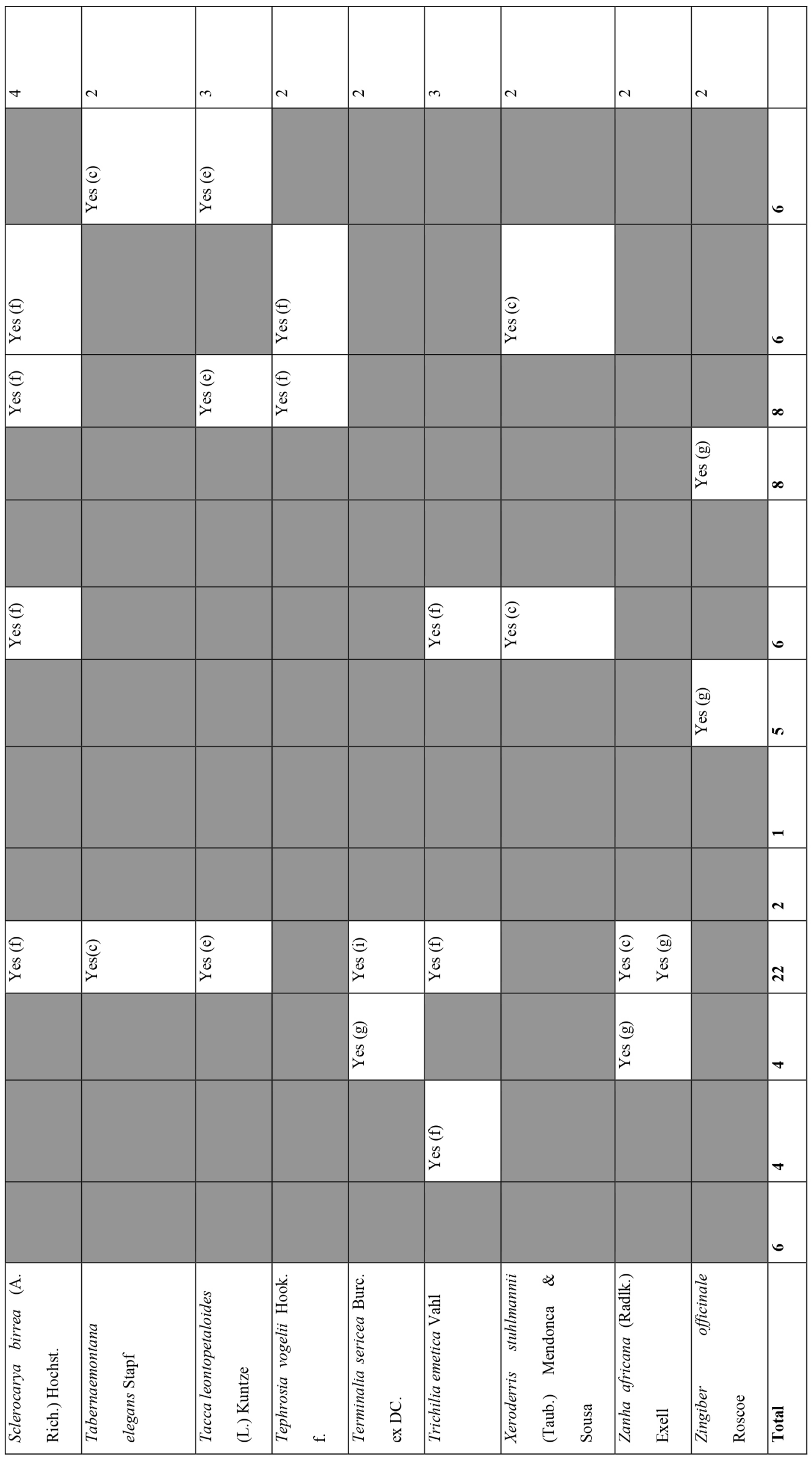


Table 5: Literature Reported Pharmacological properties of medicinal plants with potential for use in COVID-19 disease

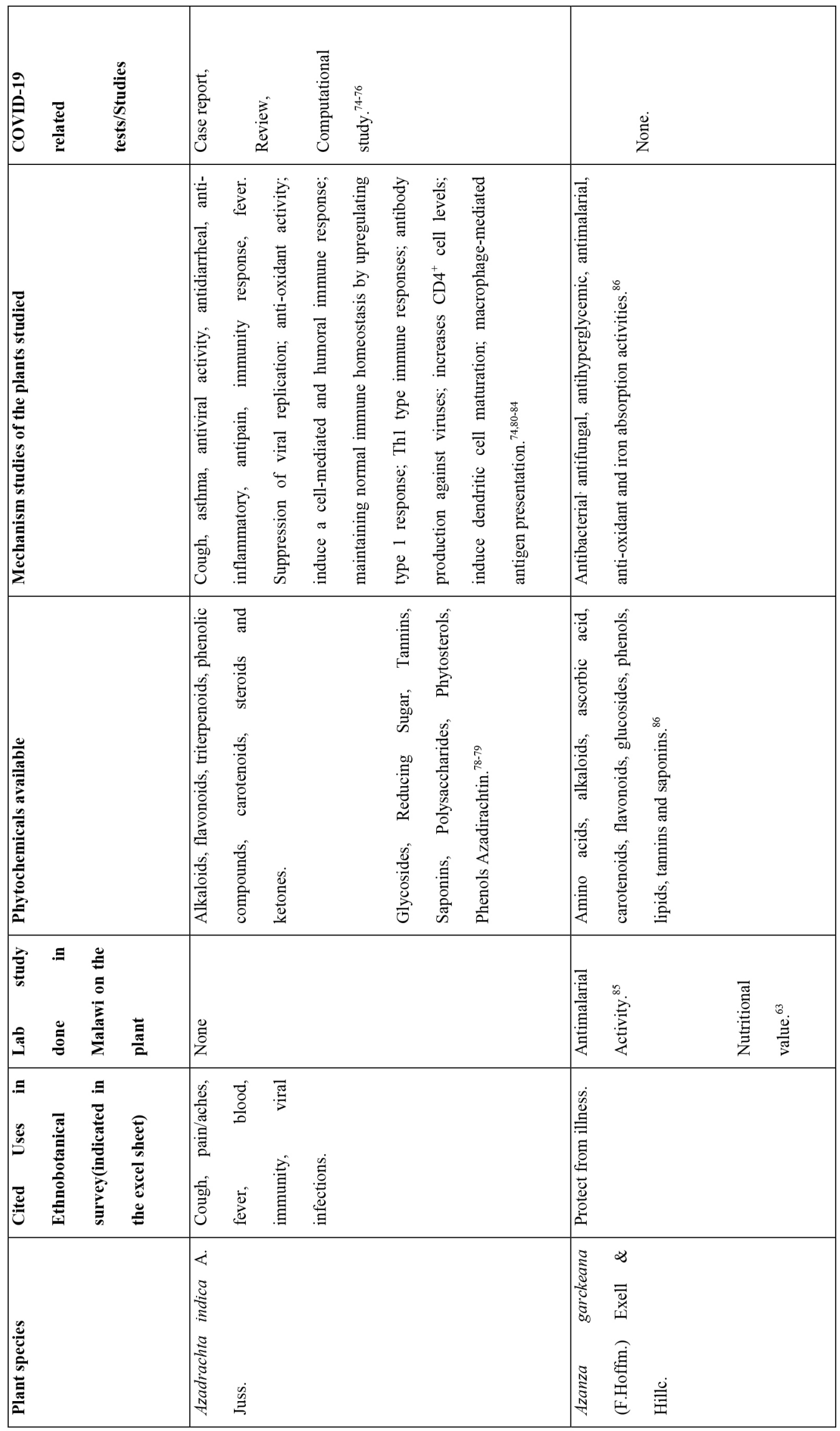


Table 5 Cont....

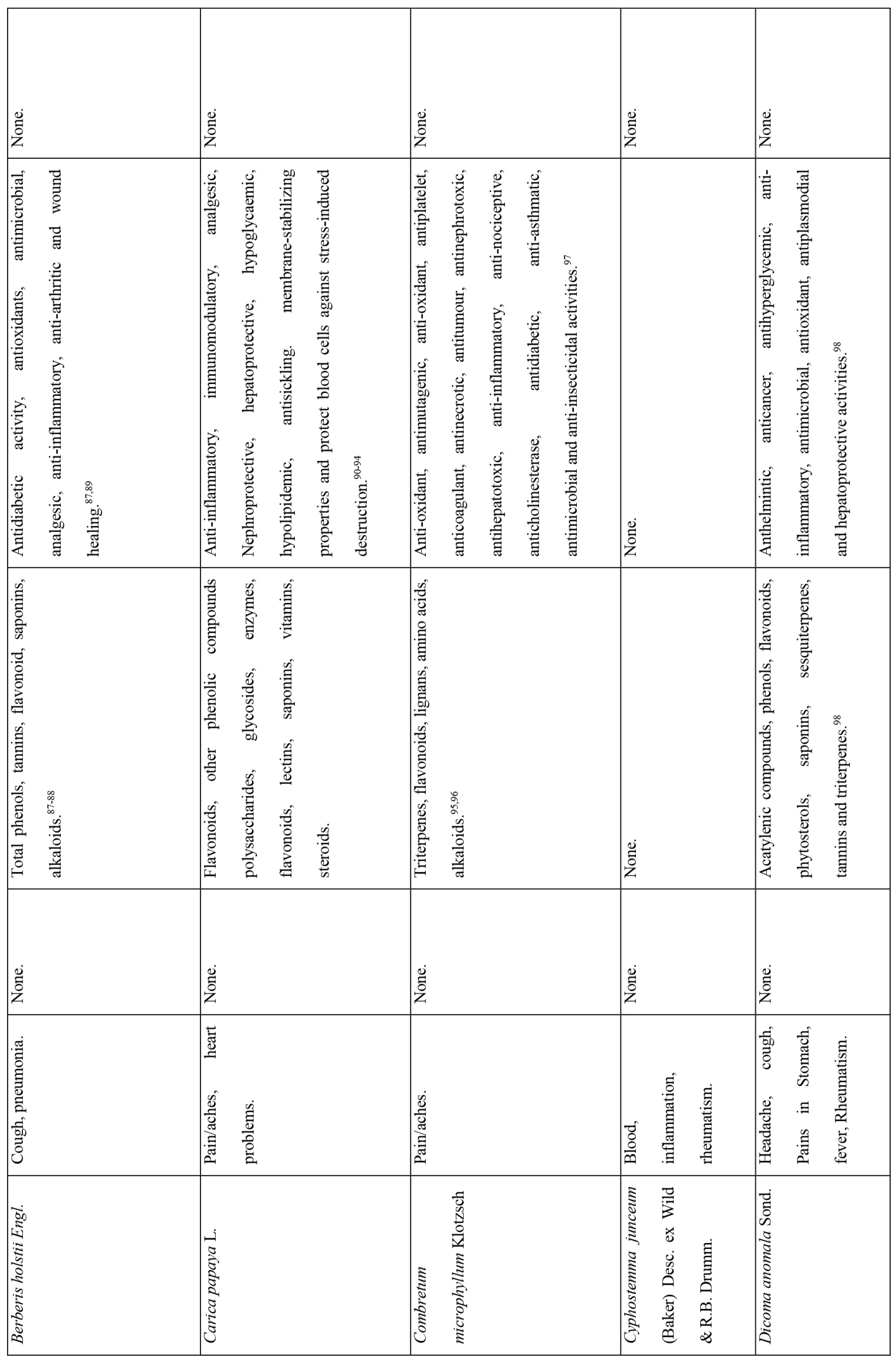




\section{Table 5 Cont....}

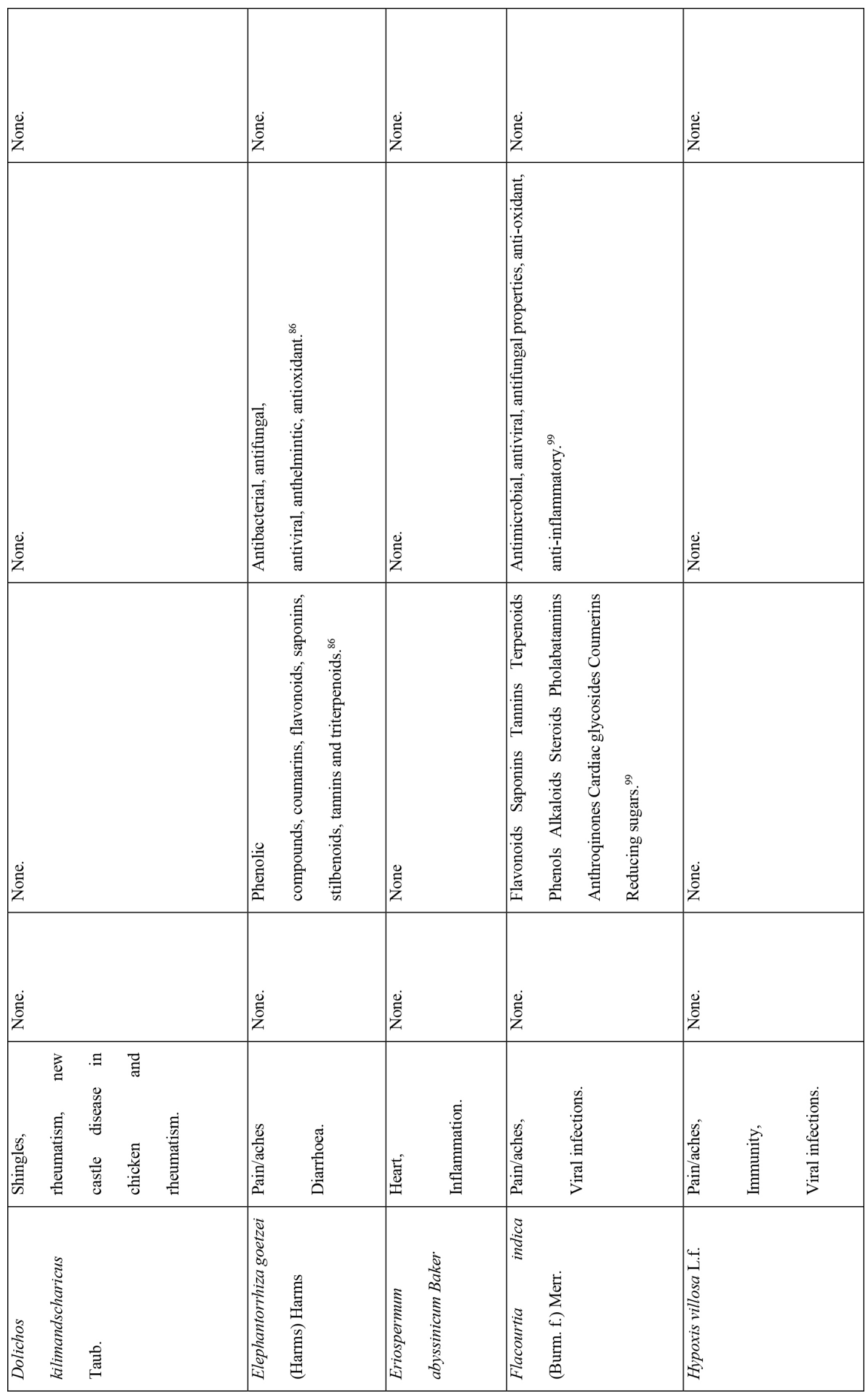




\section{Table 5 Cont....}

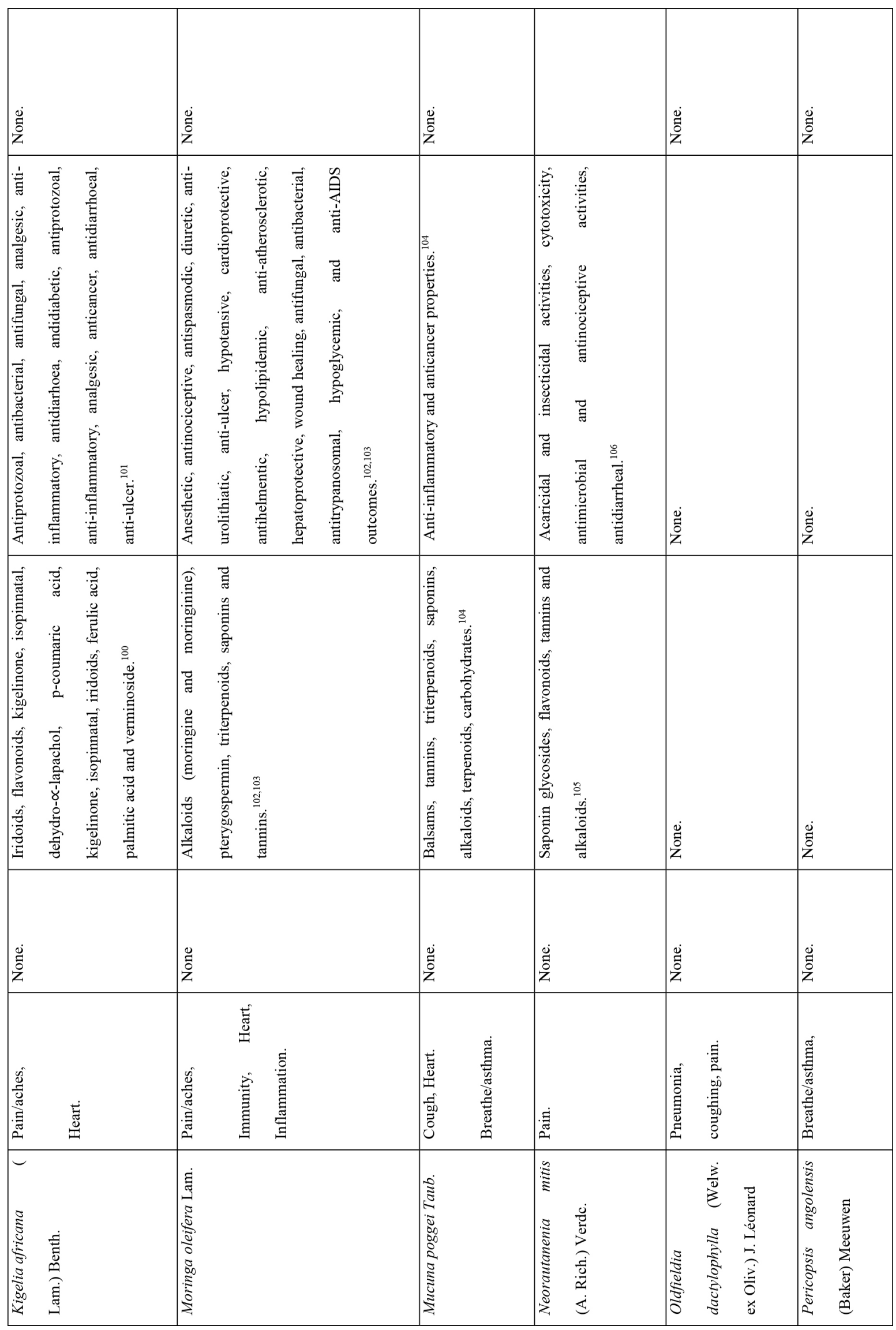




\section{Table 5 Cont....}

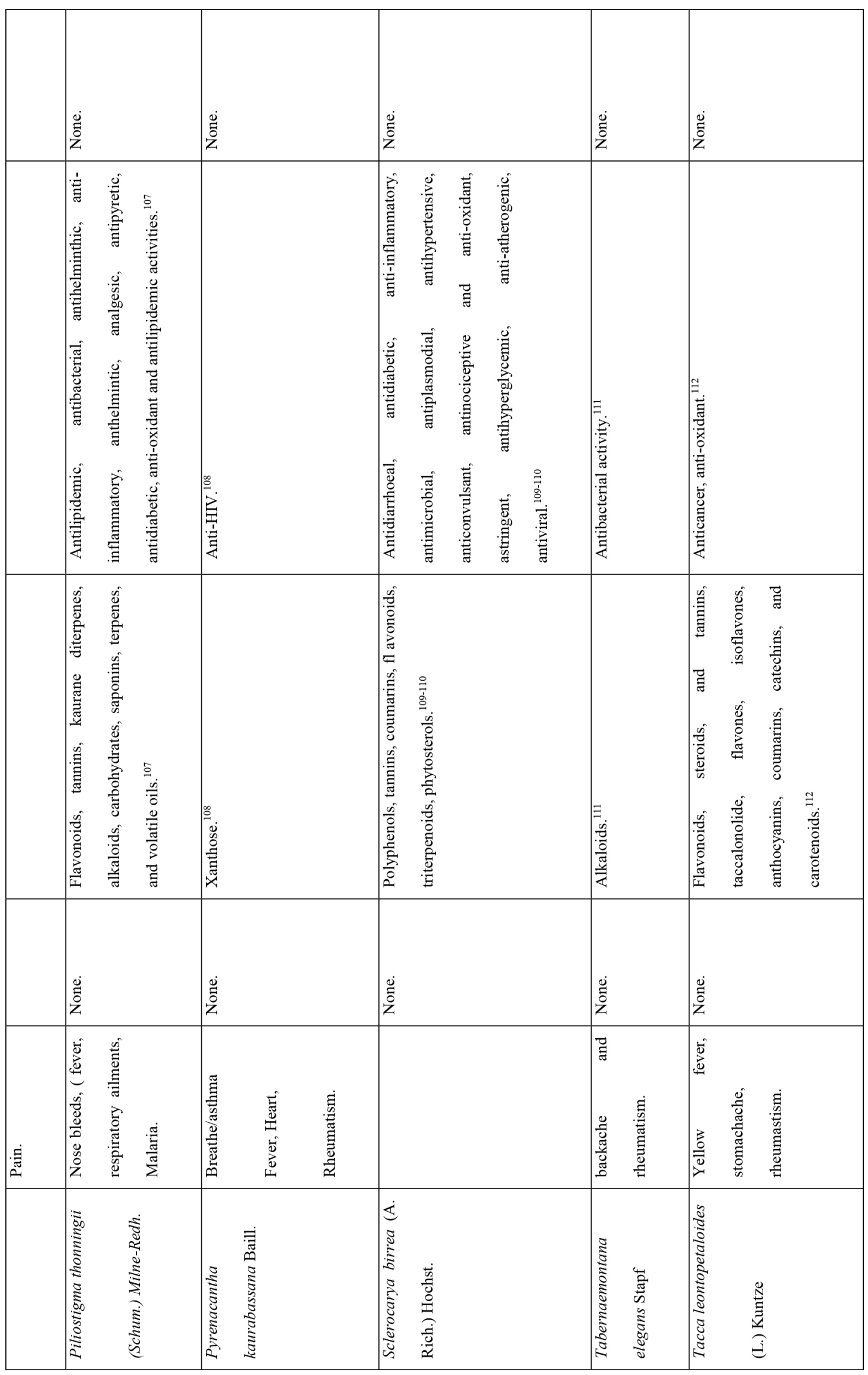


Table 5 Cont....

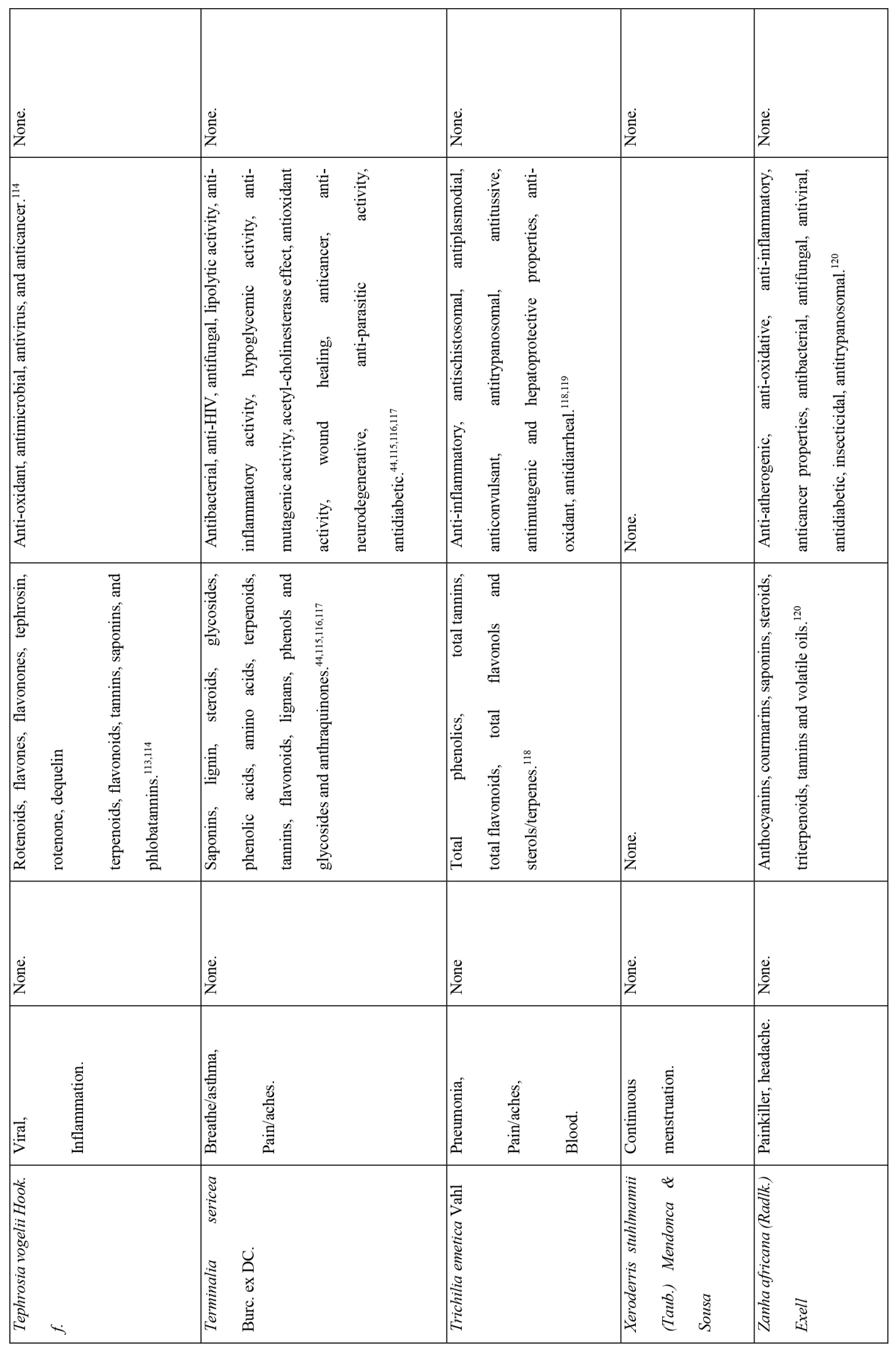




\section{Table 5 Cont....}

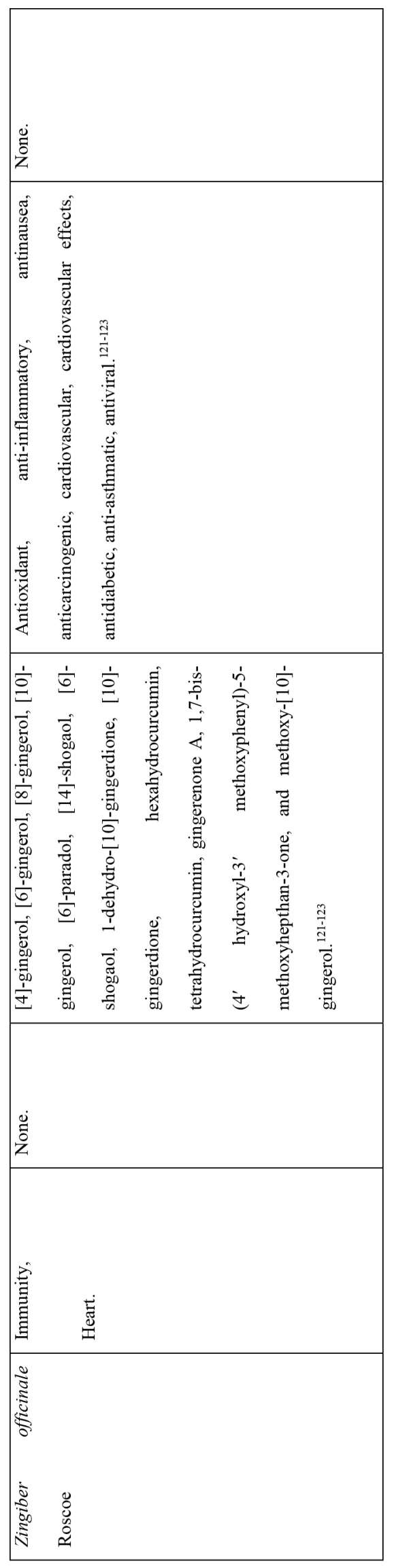

